\title{
Effects of Type of Oilseed and Level of Concentrate on Fermentation, Biohydrogenation of Fatty Acids and Conjugated Linoleic Acid Production in a Rumen-Simulated Continuous Culture System
}

\author{
N. J. Choi
}

Institute of Grassland and Environmental Research, Plas Gogerddan, Aberystwyth SY23 3EB, UK

\author{
지방급원 형태와 수준에 따른 연속배양장치 내 반추위 발효성상, \\ 지방산의 수소첨가 현상 및 Conjugated Linoleic Acid 생산에

$$
\begin{gathered}
\text { 미치는 영향 연구 } \\
\text { 최 낙 진 } \\
\text { IGER 연구소, 영국 }
\end{gathered}
$$

\begin{abstract}
This experiment employed a rumen simulated continuous culture system to examine the possibility of improving the rumen bypass of polyunsaturated fatty acids (PUFA) by using a high proportion of concentrate in the feed, and compared soya and linseed in terms of conjugated linoleic acid (CLA) production. No effect of type of fat source was observed on ruminal fermentation. A high proportion of concentrate $(80 \%)$ in the feed decreased $(\mathrm{P}<0.001)$ vessel $\mathrm{pH}$ but increased $(\mathrm{P}<0.01)$ ammonia nitrogen, total VFA, acetate, butyrate and valerate concentrations compared with a low proportion (40\%). Fat sources (soya vs. linseed) and concentrate ratio in the feed did not affect digestibilities of organic matter (OM), total nitrogen, neutral detergent fiber (NDF) and acid detergent fiber (ADF). Soya increased the flows of trans C18:1, C18:2 n- 6 and C18:3 n-3 compared with linseed. The difference in fat source alone did not affect the flow of CLA but this was increased when high levels of soya and linseed were associated with a high proportion of concentrate in the feed. There was no effect of fat source on biohydrogenation of C18:1 n-9 and C18:2 n- 6 , but biohydrogenation of $\mathrm{C} 18: 3 \mathrm{n}-3$ and total C18 PUFA was higher with the linseed than with the soya treatment. A high proportion of concentrate decreased biohydrogenation of C18:2 n-6, C18:3 n-3 and total C18 PUFA compared with a low proportion.
\end{abstract}

(Key words : Polyunsaturated fatty acids (PUFA), Conjugated linoleic acid (CLA), Biohydrogenation)

\section{I .INTRODUCTION}

Recently, there has been a lot of interest in using fats to manipulate the fatty acid compo- sition of ruminant products such as beef and milk. Clinical research has demonstrated that the n-3 polyunsaturated fatty acids (PUFA), such as C18:3 n-3, C20:5 n-3 and C22:6 n-3 are impor-

Corresponding author : N. J. Choi, School of Agricultural Biotechnology Seoul National University Suweon, 441744 Tel : 031-290-2355, Fax : 031-295-7875, E-mail : nagjin@hanmail.net

9 
tant in reducing the risk of coronary heart disease (Simopoulos, 1988). Thus, a major challenge for the animal scientists today is to establish new methods for decreasing the content of saturated fatty acid and increasing PUFA in beef and milk. Also, an interest in examining the CLA content of meat and milk has surveyed due to its anticarcinogenic effect (Ip et al., 1994). However, one of the majorlimitations for increasing the PUFA composition of ruminant products is that these fatty acids tend to be hydrogenated by rumen micro-organisms to more saturated products (Harfoot and Hazelwood, 1988). The challenge, therefore, is to increase the deposition of PUFA in beef by attempting to decrease biohydrogenation of the PUFA in the rumen. Various techniques have been used to protect dietary PUFA from biohydrogenation; such as lipids coated with formaldehyde-treated protein (Scott et al., 1972), calcium soaps (Jenkins and Palmquist, 1984), fatty acyl amides (Fotouhi and Jenkins, 1992) and feeding whole oilseeds (Scollan et al., 2001a, b). Also, feeding a high level of concentrate may decrease biohydrogenation of PUFA due to alteration of rumen metabolism (Van Nevel and Demeyer, 1996). Generally, feeding high concentrate diets decreases rumen $\mathrm{pH}$ (Galbraith and Miller, 1973; Van Nevel and Demeyer, 1996), but increases total VFA concentration (Klusmeyer et al., 1991; Hussein et al., 1996 ; Kalscheur et al., 1997b) from a rapid fermentation of high proportion of concentrates in the rumen. This results in inhibition of lipolysis (Galbraith and Miller, 1973; Van Nevel and Demeyer, 1996), and then biohydrogenation may be inhibited. In addition, a high concentrate diet increased either trans C18:1 or CLA production (Palmquist and Schanbacher, 1991; Kalscheur et al., 1997a; Griinari et al., 1998), due to incomplete biohydrogenation of fatty acids. For these reasons, it is hypothesized that a high concentrate ratio in the feed may 9 increase the deposition of PUFA and CLA in beef and milk. Therefore, an in vitro experiment using rumen simulated continuous culture (Merry et al., 1987) was conducted to investigate rumen bypass of PUFA by using high ratio of concentrate in the feed and also to look at the effect of supplemented soya high in C18:2 n-6 or linseed high in C18:3 n-3 in terms of CLA production.

\section{П. MATERIALS AND METHODS}

\section{Inoculum source}

The experimental rumen fluid was collected in thermos flasks from each of two Holstein-Friesian cows which were fed ad libitum grass silage plus approximately $8 \mathrm{~kg}$ of a dairy concentrate per day; the samples were transported to the laboratory as fast as possible. The two samples of rumen fluid were bulked and filtered through 4 layers of surgical muslin, and centrifuged at $551 \times$ g (Beckman, Model J-6B, Galway, Ireland) for 15 minutes to remove feed particles. The supernatant was centrifuged again at $31,000 \times \mathrm{g}$ (MSE High Speed 18, England) for 15 minutes. The pellet was washed with $0.9 \%$ saline and then distilled water. Centrifugation of the pellet samples was started approximately 15 minutes after collection.

\section{Experimental design, diets and infusates entering the vessel}

The experiment was conducted as a $4 \times 4$ Latin square design using 4 diets and vessels. Each experimental period lasted $12 \mathrm{~d}$, with a $9 \mathrm{~d}$ adaptation period to the diets, followed by a $3 \mathrm{~d}$ measurement period. Four diets varying in the type of fat (soya or linseed) and ratio of concentrate to forage (50:50, grass silage: barley straw on a DM basis) were used. The concen- 
trate mixes were based on wheat, molassed sugarbeet pulp and molasses with either whole linseed (n-3 PUFA source, high in C18:3 n-3) or full-fat soya bean (n-6 PUFA source, high in C18:2 n-6). These two mixes were combined with the forage in either a 60:40 (Low) or 20:80 (High) ratio of forage:concentrate on a DM basis. The formulation of the concentrates is shown in Table 1. The concentrate and forage were ground to pass through a $2 \mathrm{~mm}$ screen using a mill (Tecator, Box 70, S-263 21, Hoganas, Sweden). Each of the four concentrate/forage diets was blended with water $(1.3 \mathrm{~L} / \mathrm{kg}$ diet $)$ containing methylcellulose $(10 \mathrm{~g} / \mathrm{L})$ to bind, and pelletted. The pellets were freeze dried at $-60^{\circ} \mathrm{C}$ for $48 \mathrm{~h}$ and reduced in size to approximately $5 \mathrm{~mm}$

Table 1. Formulation and chemical composition of the experimental diets

\begin{tabular}{|c|c|c|c|c|}
\hline & \multicolumn{4}{|c|}{ Concentrate ratio } \\
\hline & High & Low & High & Low \\
\hline & \multicolumn{2}{|c|}{ Soya } & \multicolumn{2}{|c|}{ Linseed } \\
\hline Ingredient & \multicolumn{4}{|c|}{$\cdots \cdots \cdots \cdots \cdot \operatorname{lng} D M \cdots \cdots \cdots \cdots$} \\
\hline Wheat & 340 & 170 & 340 & 170 \\
\hline $\begin{array}{l}\text { Molassed sugar } \\
\text { beet pulp }\end{array}$ & 176 & 88 & 176 & 88 \\
\hline Molasses & 40 & 20 & 40 & 20 \\
\hline Full fat soya & 224 & 112 & 0 & 0 \\
\hline Linseed & 0 & 0 & 100 & 50 \\
\hline Linseed meal & 0 & 0 & 124 & 62 \\
\hline Premix & 20 & 10 & 20 & 10 \\
\hline Grass silage & 100 & 300 & 100 & 300 \\
\hline Barley straw & 100 & 300 & 100 & 300 \\
\hline \multicolumn{5}{|c|}{ Chemical composition $\cdots \cdots \cdots \cdots \cdot \mathrm{g} / \mathrm{kg} D M \cdots \cdots \cdots \cdots$} \\
\hline $\mathrm{DM}$ & 968.0 & 961.4 & 978.5 & 946.0 \\
\hline Total nitrogen & 28.0 & 20.7 & 24.3 & 19.2 \\
\hline Organic matter & 930.0 & 937.5 & 929.6 & 935.5 \\
\hline $\begin{array}{l}\text { Neutral detergent } \\
\text { fibre }\end{array}$ & 351.4 & 558.3 & 374.4 & 579.1 \\
\hline $\begin{array}{l}\text { Acid detergent } \\
\text { fibre }\end{array}$ & 133.0 & 290.2 & 166.6 & 306.5 \\
\hline $\begin{array}{l}\text { Acid hydrolysis } \\
\text { ether extract }\end{array}$ & 70.1 & 44.6 & 71.2 & 44.0 \\
\hline
\end{tabular}

lengths. The dietary pellets were delivered continuously into vessels by an automatic feeder at a rate of $30 \mathrm{~g} \mathrm{DM} / \mathrm{d}$ and artificial saliva (Mc Dougall, 1948) was infused continuously at approximately $1450 \mathrm{ml} / \mathrm{d}$ by a peristaltic pump.

\section{Procedures and measurements}

During the experiment, samples of filtered and displaced effluent were taken daily just after replenishing the feed. Samples of filtered and displaced effluent were combined in proportion to the amounts collected (mixed effluent) during the sampling days (days 10, 11 and 12). About 300g samples of mixed effluent per vessel were collected and freeze dried at $-60^{\circ} \mathrm{C}$ for $48 \mathrm{~h}$ for subsequent analyses of DM, OM, VFA, NDF/ ADF, total-N and fatty acids. Another $150 \mathrm{ml}$ of mixed effluent samples as a liquid form were taken and frozen at $-20^{\circ} \mathrm{C}$ for analyses of volatile fatty acids and ammonia nitrogen. Daily samples $(8 \mathrm{ml})$ were taken of filtered vessel contents and the $\mathrm{pH}$ was measured immediately. The calculation of biohydrogenation followed the method of $\mathrm{Wu}$ et al. (1991) : biohydrogenation $(\%)=100-100 \times$ (individual unsaturated $\mathrm{C} 18 /$ total $\mathrm{C} 18$ in duodenal digesta)/ (individual unsaturated $\mathrm{C} 18 /$ total $\mathrm{C} 18$ in feed).

\section{Analytical methods}

The DM content of diets was measured after drying at $100^{\circ} \mathrm{C}$ for $24 \mathrm{~h}$. OM was analysed by ashing at $550^{\circ} \mathrm{C}$ for $6 \mathrm{~h}$ in a muffle furnace. Volatile components of rumen liquid were determined by gas chromatography for VFA. Ammonia nitrogen $\left(\mathrm{NH}_{3}-\mathrm{N}\right)$ was assessed enzymatically using glutamate dehydrogenase on a discrete analyser (FP-901M Chemistry Analyzer, Labsystems Oy, Helsinki, Finland; test kit no 6650, Sigma-Aldrich Co, Ltd, Poole, Dorset). Total nitrogen was determined by the micro-Kjeldahl 
technique using 'Kjeltec equipment' (Perstorp Analytical Ltd, Maidenhead, Berkshire). NDF was determined as described by Van Soest et al. (1991) using the Tecator Fibretec System equipment (Tecator Ltd, Thornbury, Bristol). Acid hydrolysis ether extracts (AHEE) were obtained using 'Soxtec' equipment (Perstorp Analytical Ltd, Maidenhead, Berkshire) incorporating the additional acid hydrolysis and extraction step as described in Ministry of Agriculture, Fisheries and Food (1992).

Fatty acids from mixed effluents and bacteria were obtained by direct hydrolysis in $5 \mathrm{M}$ potassium hydroxide in aqueous methanol (1:1, $\mathrm{v}: \mathrm{v})$ for $3 \mathrm{~h}$ at $60^{\circ} \mathrm{C}$, after addition of $\mathrm{C} 21: 0$ standard methyl ester as an internal standard. After acidification and extraction into petroleum spirit the fatty acids were converted to methyl esters using a solution of diazomethane in diethyl ether (Enser et al., 1996). Methyl ester composition was analysed by gas-liquid chromatography on a CP Sil 88 column $(50 \mathrm{~m} \times 0.25 \mathrm{~mm}$ ID $)$ (Chrompack, UK) using a split injection system and helium as carrier gas. A standard of mixed isomers of CLA methyl esters was obtained from Sigma Chemical Co. (Poole, UK). The CLA isomers of the standard eluted form the column after a-linolenic acid in the region of the internal standard were determined by methods similar to those reported previously (Jiang et al., 1996; Stanton et al., 1997). At the column loadings used only one peak was detected in the sample's lipids corresponding to a peak in the CLA standard.

\section{Statistical analysis}

Analysis of variance was used to identify type of fat and concentrates: forage ratio effects and their interactions using Genstat 5, (Lawes Agricultural Trust, 1990). The model fitted was :$$
\mathrm{Y}_{i j k l}=\mu+\mathrm{C}_{i}+\mathrm{F}_{j}+\mathrm{CF}_{i j}+\mathrm{V}_{k}+\mathrm{P}_{l}+\mathrm{E}_{i j k l}
$$

Where $\mu$ is the overall mean, $\mathrm{Ci}$ is the fixed effect of the $i^{\text {th }}$ concentrate ratio $(i=1,2), \mathrm{F}_{j}$ is the fixed effect of the $j^{\text {th }}$ fat source $(j=1,2)$, $\mathrm{CF}_{\mathrm{ij}}$ is the interaction term of the $i^{\text {th }}$ concentrate ratio with the $j^{\text {th }}$ fat source, $\mathrm{V}_{k}$ is the fixed effect of the $k^{\text {th }}$ vessel $(k=1-4), \mathrm{P}_{l}$ is the fixed effect of the $l^{\text {th }}$ period $(l=1-4)$ and $\mathrm{E}_{i j k l}$ is the residual error term.

\section{RESULTS}

\section{Diet composition}

The four experimental diets had a similar DM and $\mathrm{OM}$ contents (Table 1). There was a difference in the total- $\mathrm{N}$ content between soya and linseed, particularly in the diets with a high ratio of concentrate diets because the concentrates were not iso-nitrogenous. The total-N and Acid hydrolysis ether extract (AHEE) were higher but NDF and $\mathrm{ADF}$ were lower in the diets containing the higher proportion of concentrate.

The fatty acid composition of the diets is shown in Table 2. Total fatty acid was higher in the high than in the low concentrate diets. C18:2 n-6 was the major fatty acid in the diet containing soya, representing $51 \%$ and $46 \%$ of total fatty acid in high and low concentrate diets, respectively. In the diets containing linseed, C18:3 n-3 was the major fatty acid, representing 54\%

Table 2. Fatty acid composition of the experimental diets ( $\mathrm{g} / \mathrm{kg} \mathrm{DM})$

\begin{tabular}{|c|c|c|c|c|}
\hline & \multicolumn{4}{|c|}{ Concentrate ratio } \\
\hline & High & Low & High & Low \\
\hline & \multicolumn{2}{|c|}{ Soya } & \multicolumn{2}{|c|}{ Linseed } \\
\hline $\mathrm{C} 14: 0$ & 0.10 & 0.12 & 0.38 & 0.28 \\
\hline $\mathrm{C} 16: 0$ & 7.58 & 4.42 & 6.85 & 4.35 \\
\hline C18:0 & 1.75 & 0.94 & 2.38 & 1.31 \\
\hline C18:1n-9 & 10.46 & 5.19 & 11.61 & 5.76 \\
\hline C18:2n-6 & 27.25 & 13.69 & 13.77 & 7.64 \\
\hline C18:3n-3 & 4.03 & 3.33 & 33.38 & 18.19 \\
\hline Total fatty acid & 53.63 & 29.64 & 61.34 & 38.12 \\
\hline
\end{tabular}


and $48 \%$ of total fatty acid in high and low concentrate diets, respectively. These two fatty acids, 18:2 n-6 in soya and C18:3 n-3 in linseed diets, were present at almost similar levels.

\section{Characteristics of fermentation and di- gestibilities of nutrients}

No effects of type of fat source were observed on $\mathrm{pH}, \mathrm{NH}_{3}-\mathrm{N}$ and total VFA in the fermenter vessels (Table 3). Concentrations of individual VFA were also not significantly different between the treatments, including type of fat source, except n-valerate, which was higher in soya compared to linseed treatments $(\mathrm{P}<$ 0.01). High concentrate diets decreased the vessel $\mathrm{pH}$ $(\mathrm{P}<0.001)$, but increased $\mathrm{NH}_{3}-\mathrm{N}(\mathrm{P}<0.01)$ and total VFA $(\mathrm{P}<0.01)$ compared to low concentrate diets. The concentration of all VFA was higher in the high concentrate diets, except for propionate. Digestibilities of nutrients including OM, total-N, $\mathrm{NDF}$ and ADF were not affected by fat sources and / or concentrate ratios in the feed (Table 4).

Table 3. Effect of type of fat and proportion of concentrates in the diet on fermentation in rumen simulated vessels

\begin{tabular}{|c|c|c|c|c|c|c|c|}
\hline & & Conce & e ratio & & \multirow[b]{3}{*}{$\mathrm{SED}^{1)}$} & \multirow{2}{*}{\multicolumn{2}{|c|}{$\mathrm{P}$ value $\mathrm{e}^{2)}$}} \\
\hline & High & Low & High & Low & & & \\
\hline & \multicolumn{2}{|c|}{ Soya } & \multicolumn{2}{|c|}{ Linseed } & & Fat source & $\mathrm{F}: \mathrm{C}^{3)}$ \\
\hline $\mathrm{pH}$ & 6.10 & 6.54 & 6.19 & 6.50 & 0.068 & NS & $* * *$ \\
\hline $\mathrm{NH}_{3}-\mathrm{N}(\mathrm{mgN} / \mathrm{L})$ & 162.9 & 119.1 & 149.3 & 120.9 & 12.48 & NS & $* *$ \\
\hline Total VFA $(\mathrm{mmol} / \mathrm{L})$ & 81.61 & 66.80 & 76.91 & 63.92 & 3.524 & NS & $* *$ \\
\hline \multicolumn{8}{|c|}{ Individual VFA molar proportion $(\mathrm{mmol} / \mathrm{L})$} \\
\hline Acetate & 45.98 & 40.78 & 45.25 & 39.92 & 1.753 & NS & $* *$ \\
\hline Propionate & 16.71 & 12.79 & 14.24 & 12.75 & 2.587 & NS & NS \\
\hline Iso-butyrate & 0.87 & 0.63 & 0.81 & 0.64 & 0.078 & NS & $* *$ \\
\hline n-butyrate & 13.85 & 9.95 & 13.34 & 8.43 & 1.689 & NS & $*$ \\
\hline Iso-valerate & 1.47 & 0.85 & 1.15 & 0.75 & 0.158 & NS & $* *$ \\
\hline n-valerate & 2.74 & 1.80 & 2.11 & 1.44 & 0.184 & $* *$ & $* * *$ \\
\hline $\mathrm{A} / \mathrm{P}$ ratio & 3.04 & 3.28 & 3.26 & 3.18 & 0.299 & NS & NS \\
\hline
\end{tabular}

${ }^{1)} \mathrm{SED}=$ standard error deviation.

${ }^{2)}$ The interaction effect was not significant $(\mathrm{P}>0.05) ; \mathrm{NS}=$ not significant $(\mathrm{P}>0.05),{ }^{*} \mathrm{P}\langle 0.05, * * \mathrm{P}\langle 0.01$ and $* * * \mathrm{P}<0.001$

${ }^{3)} \mathrm{F}: \mathrm{C}$, ratio of forage to concentrate.

Table 4. Effect of diet and forage:concentrate ratio $(\mathrm{F}: \mathrm{C})$ on the digestibility of nutrients in rumen simulated vessels

\begin{tabular}{|c|c|c|c|c|c|c|c|c|}
\hline & \multicolumn{4}{|c|}{ Concentrate ratio } & \multirow[b]{3}{*}{$\mathrm{SED}^{1)}$} & \multicolumn{3}{|c|}{$P$ value ${ }^{2)}$} \\
\hline & High & Low & High & Low & & & & \\
\hline & \multicolumn{2}{|c|}{ Soya } & \multicolumn{2}{|c|}{ Linseed } & & Fat source & $F: C^{3)}$ & Interaction \\
\hline \multicolumn{9}{|c|}{ Digestibility (\%) } \\
\hline OM & 72.9 & 68.3 & 72.2 & 69.3 & 3.881 & NS & NS & NS \\
\hline Total N & 36.4 & 40.3 & 36.6 & 41.0 & 3.771 & NS & NS & NS \\
\hline $\mathrm{NDF}$ & 54.7 & 50.2 & 49.0 & 50.8 & 2.08 & NS & NS & NS \\
\hline $\mathrm{ADF}$ & 48.4 & 47.5 & 44.8 & 46.7 & 2.68 & NS & NS & NS \\
\hline
\end{tabular}

1),2,3) As Table 3 .

9 
3. Intake, outflow and biohydrogenation of C18 fatty acids

Intakes and outflows of $\mathrm{C} 18$ fatty acids, and outflows of trans C18:1 and CLA are presented in Table 5. Since OM intake was similar between two treatments, the difference in $\mathrm{C} 18$ fatty acids intake is the reflection of the differences in the composition of the diets. Intake of C18:2 n-6 was higher in soya than in linseed treatments $(\mathrm{P}<0.001)$. Intakes of $\mathrm{C} 18: 1 \mathrm{n}-9$ and $\mathrm{C} 18: 3 \mathrm{n}-3$ were higher in linseed than in soya treatments ( $\mathrm{P}<0.001$ and $\mathrm{P}\langle 0.001$, respectively). The outflows of C18:1 n-9, C18:2 n-6 and C18:3 n-3 showed correspondence with intakes. Different types of fat source did not affect flow of CLA, but the flow of trans $\mathrm{C} 18: 1$ was higher in the soya than in the linseed treatment $(\mathrm{P}<0.05)$. As expected, intakes of $\mathrm{C} 18$ fatty acids were higher with the high with the low concentrate diets $(\mathrm{P}<$
0.001). Flows of CLA and trans C18:1 were higher with high than with low concentrate $(\mathrm{P}<$ 0.05). Intakes of $\mathrm{C} 18: 1 \mathrm{n}-9$ and $\mathrm{C} 18: 3 \mathrm{n}-3$ were higher in both the high and low concentrate diets containing linseed than in those containing soya ( $\mathrm{P}<0.001$ and $\mathrm{P}<0.001$, respectively), but intakes of C18:2 n-6 were higher in both the diets containing soya $(\mathrm{P}<0.001)$.

Effects of diets on biohydrogenation of $\mathrm{C} 18$ fatty acids are shown in Table 6. Biohydrogenation of C18:1 n-9 and C18:2 n-6 were not affected by type of fat source. Biohydrogenation of $\mathrm{C} 18: 3 \mathrm{n}-3$ and total $\mathrm{C} 18$ unsaturated fatty acids were lower in soya than that of linseed treatments ( $\mathrm{P}<0.05$ and $\mathrm{P}<0.05$, respectively). High concentrate diets decreased biohydrogenation of $\mathrm{C} 18: 2 \mathrm{n}-6, \mathrm{C} 18: 3 \mathrm{n}-3$ and total $\mathrm{C} 18$ unsaturated fatty acids compared to low concentrate diets $(\mathrm{P}<0.05)$.

Table 5. Effect of type of fat sources and proportion of concentrates in the diet on CLA production

\begin{tabular}{|c|c|c|c|c|c|c|c|c|}
\hline & \multicolumn{4}{|c|}{ Concentrate ratio } & \multirow[b]{3}{*}{$\mathrm{SED}^{1)}$} & \multicolumn{3}{|c|}{$P$ value ${ }^{2)}$} \\
\hline & \multirow{2}{*}{$\frac{\text { High }}{\text { So }}$} & \multirow{2}{*}{$\begin{array}{l}\text { Low } \\
\text { a }\end{array}$} & \multirow{2}{*}{\multicolumn{2}{|c|}{$\begin{array}{c}\text { High Low } \\
\text { Linseed }\end{array}$}} & & \multirow{3}{*}{ Fat source } & & \\
\hline & & & & & & & \multirow[t]{2}{*}{$F: C^{3)}$} & \multirow[t]{2}{*}{ Interaction } \\
\hline \multicolumn{6}{|c|}{ Organic matter $(O M)$} & & & \\
\hline Intake $(g / d)$ & 26.6 & 26.3 & 26.8 & 26.3 & 0.247 & NS & NS & NS \\
\hline Flow (g/d) & 7.8 & 7.5 & 8.0 & 7.5 & 0.560 & NS & NS & NS \\
\hline \multicolumn{9}{|c|}{ Intake $(\mathrm{mg} / \mathrm{d})$} \\
\hline C18:1n-9 & 259 & 128 & 289 & 140 & 1.527 & $* * *$ & $* * *$ & $* * *$ \\
\hline C18:2n-6 & 673 & 339 & 343 & 186 & 3.039 & $* * *$ & $* * *$ & *** \\
\hline C18:3n-3 & 100 & 82.4 & 831 & 442 & 3.435 & $* * *$ & $* * *$ & $* * *$ \\
\hline \multicolumn{9}{|c|}{ Flow $(\mathrm{mg} / \mathrm{d})$} \\
\hline C18:1n-9 & 62.7 & 31.4 & 56.2 & 26.6 & 5.48 & NS & $* * *$ & NS \\
\hline C18:2n-6 & 92 & 41 & 36 & 17 & 9.67 & $* *$ & $* *$ & NS \\
\hline C18:3n-3 & 15 & 10 & 78 & 27 & 12.34 & $* *$ & * & * \\
\hline Trans C18:1 & 117 & 69 & 71 & 32 & 19.06 & * & * & NS \\
\hline CLA & 3.4 & 1.3 & 2.8 & 1.0 & 0.733 & NS & * & NS \\
\hline
\end{tabular}

1),2,3) As Table 3.

The calculation of intake and flow of fatty acids was based on OM.

9 
Table 6. Effect of type of fat and proportion of concentrates in the diet on biohydrogenation of C18 fatty acids

\begin{tabular}{|c|c|c|c|c|c|c|c|c|}
\hline & \multicolumn{4}{|c|}{ Concentrate ratio } & \multirow[b]{3}{*}{ SED $^{1)}$} & \multicolumn{3}{|c|}{$P$ value ${ }^{2)}$} \\
\hline & High & Low & High & Low & & & & \\
\hline & \multicolumn{2}{|c|}{ Soya } & \multicolumn{2}{|c|}{ Linseed } & & Fat source & $\mathrm{F}: \mathrm{C}^{3)}$ & Interaction \\
\hline & \multicolumn{5}{|c|}{ percentage $(\%)$} & & & \\
\hline C18:1 n-9 & 65.2 & 61.2 & 61.0 & 60.0 & 3.460 & NS & NS & NS \\
\hline C18:2 n-6 & 80.2 & 81.9 & 80.0 & 82.0 & 1.306 & NS & $*$ & NS \\
\hline C18:3 n-3 & 78.5 & 82.1 & 82.0 & 87.6 & 2.412 & $*$ & $*$ & NS \\
\hline Total C18 & 76.3 & 77.1 & 77.1 & 81.6 & 1.192 & $*$ & $*$ & NS \\
\hline
\end{tabular}

1),2),3) As Table 3.

\section{DISCUSSION}

This study has shown that ruminal fermentation and digestibilities of nutrients were not affected by the type of fat source, which may indicate that the fats did not exert negative effects on microbial activity in the rumen. The outflow of C18 fatty acids was influenced by dietary $\mathrm{C} 18$ fatty acids and the extent of biohydrogenation of these fatty acids did not differ between fat sources. Data from recent in vivo studies showed that biohydrogenation varied from $30 \%$ to $84 \%$ for $\mathrm{C} 18: 1 \mathrm{n}-9,60 \%$ to $95 \%$ for $\mathrm{C} 18: 2 \mathrm{n}-6$, and $58 \%$ to $100 \%$ for $\mathrm{C} 18: 3 \mathrm{n}-3$ (Klusmeyer and Clark, 1991; Wu et al., 1991; Enjalbert et al., 1994; Hussein et al., 1996; Aldrich et al., 1997; Kalscheur et al., 1997a,b; Elizalde et al., 1999). Those results imply that biohydrogenation of unsaturated fatty acids increases as unsaturation increases. In this study, biohydrogenation of C18:1 n-9, C18:2 n-6 and C18:3 n-3 were approximately 62,81 and $83 \%$, respectively. Therefore, the present results in this study are in agreement with previous reports in that biohydrogenation increases as unsaturation increases. The extent of biohydrogenation of $\mathrm{C} 18: 1 \mathrm{n}-9$ in the present study was lower than that of other PUFA. This may be explained by the fact that $\mathrm{C} 18: 1 \mathrm{n}-9$ is hydrogenated directly to C18:0 (Harfoot, 1978; Harfoot and Hazlewood, 1988). Therefore, C18:1 9 n-9 would not be expected to be the precursor for trans C18:1 or CLA. Since the intake of C18 fatty acids was higher in linseed treatments compared to soya treatments, it may be expected that biohydrogenation of $\mathrm{C} 18$ fatty acids were decreased due to inhibition of microbial activity. However, biohydrogenation of C18:2 n-6 was not significantly different between the treatmentms, but biohydrogenation of C18:3 n-3 was higher in linseed compared to soya treatments. Therefore, it appears that a relatively high intake of $\mathrm{C} 18$ PUFA in linseed did not negatively affect microorganisms with rumen $\mathrm{pH}$ above 6.2. Also, ruminal digestibilities of nutrients were not affected by the type of fat source. In the ruminal biohydrogenation of C18:2 n-6, CLA is a transient intermediate, whereas trans C18:1 accumulates (Harfoot and Hazlewood, 1988). In muscle and milk, there was a strong linear correlation between levels of CLA and trans C18:1 (Jiang et al., 1996; Jahreis et al., 1997; Enser et al., 1999). Enser et al. (1999) reported that the increased levels of both trans C18:1 and CLA could result from similar proportional inhibition of both enzymes by the dietary n-3 PUFA or feedback inhibition of CLA reductase by increased concentrations of trans $\mathrm{C} 18: 1$ in the rumen.

This study has demonstrated a significant effect of concentrate ratio on rumen metabolism in accordance with previous reports (Nocek, 1997), 
and this is related to a lower level of biohydrogenation of C18:2 n-6, C18:3 n-3 and total C18 unsaturated fatty acids with diets containing a high compared a low proportion of concentrate. Recent data have shown that high dietary levels of concentrate decreased biohydrogenation (Kalscheur et al., 1997a; Hussein et al., 1996). In addition, higher flows of trans C18:1 and CLA in high concentrate diets may indicate inhibition of biohydrogenation of C18:2 n-6 in high concentrate diets was lower compared to low concentrate diets. As shown in Table 2, feeding a high proportion of concentrate resulted in a relatively higher level of unsaturated fatty acids, C18:2 n-6 and C18:3 n-3, compared to a low proportion. Unsaturated fatty acids are more likely to alter microbial fermentation due to their greater effect on bacterial growth compared with saturated fatty acids (Maczulak et al., 1981; Jenkins, 1993). This is due to the nature of unsaturated fatty acids, which coat feed particles and are more available to exert toxic effects on ruminal micro organisms (Harfoot, 1978; Chalupa et al., 1984). Alternatively, high concentrate diets increased VFA concentration as a result of rapid fermentation of carbohydrate, and decreased rumen $\mathrm{pH}$. Therefore, a high concentrate diet has a negative effect on microbial activity, reducing the biohydrogenation process. However, a high proportion of concentrate did not affect digestibilities of nutrients, suggesting diets did not negatively affect rumen micro- organisms. This is demonstrated by the vessel (rumen) $\mathrm{pH}$ values which were 6.1 across concentrate ratios. Mertens (1977) and Mould et al. (1983) reported that rumen fermentation was not altered at ruminal $\mathrm{pH}$ above 6.2. As explained above, biohydrogenation of C18:1 n-9 was not significantly different between two different ratios of concentrates.

In conclusion, our data show that rumen fermentation characteristics and extent of biohydrog9 enation were not affected by type of oilseed but were affected by the level of concentrate in the diet.

$$
\text { V. 요 약 }
$$

본 연구는 사료 내 농후사료의 비율을 높임 으로서 불포화 지방산의 반추위 내 by-pass율의 향상 가능성을 조사하고, 아마종실과 전지대두 급여 시 CLA 생산을 상호 비교하기 위하여 연 속배양장치를 이용하여 수행하였다. 지방 급원 에 따른 발효 성상의 차이는 보이지 않았다. 한편 사료 내 농후사료 비율이 높은 $(80 \%)$ 처 리구는 농후사료 비율이 낮은 $(40 \%)$ 처리구와 비교하여 $\mathrm{pH}$ 는 감소하였으나, 암모니아, 총 휘 발성 지방산, acetate, butyrate 및 valerate 농도 가 증가되었다. 지방급원 (전지대두 vs 아마종 실)과 사료 내 농후사료 비율은 organic matter $(\mathrm{OM})$, total nitrogen, neutral detergent fiber (NDF) 및 acid detergent fiber (ADF)의 소화율에 영향을 끼치지 않았다. 반면에 전지대두는 아 마종실과 비교하여 trans C18:1, C18:2 n-6 및 $\mathrm{C} 18: 3 \mathrm{n}-3$ 유출율은 증가시켰다. 지방 급원에 의한 CLA flow는 영향을 받지 않았으나 사료 내 농후사료 비율이 높을 때와 전지대두와 아 마종실의 함량이 높았을 때는 증가되었다. 수 소 첨가현상은 $\mathrm{C} 18: 1 \mathrm{n}-9$ 와 $\mathrm{C} 18: 2 \mathrm{n}-6$ 에서 지 방 급원에 의하여 영향을 받지 않았으나, 아마 종실 처리구에서는 $\mathrm{C} 18: 3 \mathrm{n}-3$ 과 총 $\mathrm{C} 18$ 불포 화지방산의 수소 첨가현상이 전지대두 처리구 와 비교하여 높은 비율로 발생했다. 한편 사료 내 농후사료 비율이 높을 때 처리구에서 $\mathrm{C} 18: 2$ $\mathrm{n}-6, \mathrm{C} 18: 3$ n-3 및 총 $\mathrm{C} 18$ 불포화 지방산의 수 소 첨가현상은 농후사료 저 처리구와 비교하여 감소되었다.

\section{REFERENCES}

1. Aldrich, C. G., Merchen, N. R., Drackley, J. K., Jr. Fahey, G. C. and Berger, L. L. 1997. The effects of chemical treatment of whole canola seed on intake, nutrient digestibilities, milk production, and milk fatty acids of Holstein cows. J. Anim. Sci. 
75:512-521.

2. Chalupa, W., Rickabaugh, B., Kronfeld, D. S. and Sklan, D. 1984. Rumen fermentation in vitro as influenced by long chain fatty acids. J. Dairy Sci. 67:1439-1444.

3. Elizalde, J. C., Aldrich, C. G., LaCount, D. W., Drackley, J. K. and Merchen, N. R. 1999. Ruminal and total tract digestibilities in steers fed diets containing liquefied or prilled saturated fatty acids. J. Anim. Sci. 77:1930-1939.

4. Enjalbert, F., Nicot, M. C., Vernay, M., Moncoulon, R. and Griess, D. 1994. Effect of different forms of polyunsaturated fatty acids on duodenal and serum fatty acid profiles in sheep. Can. J. Anim. Sci. 74: 595-600.

5. Enser, M., Hallett, K., Hewett, B., Fursey, G. A. F. and Wood, J. D. 1996. Fatty acid content and composition of English beef, lamb and pork at retail. Meat Sci. 42:443-456.

6. Enser, M., Scollan, N. D., Choi, N. J., Kurt, E., Hallett, K. and Wood, J. D. 1999. Effect of dietary lipid on the content of conjugated linoleic acid (CLA) in beef muscle. Anim. Sci. 69:143-146.

7. Fotouhi, N. and Jenkins, T. C. 1992. Resistance of fatty acyl amides to degradation and hydrogenation by ruminal microorganisms. J. Dairy Sci. 75:15271532.

8. Galbraith, H. and Miller, T. B. 1973. Effect of metal cations and $\mathrm{pH}$ on the antibacterial activity and uptake of long chain fatty acids. J. Appl. Bact. 36:659-675.

9. Griinari, J. M., Dwyer, D. A., McGuire, M. A., Bauman, D. E., Palmquist, D. L and Nurmela, K. V. V. 1998. Trans-octadecenoic acids and milk fat depression in lactating dairy cows. J. Dairy Sci. 81:1251-1261.

10. Harfoot, C. G. 1978. Lipid metabolism in the rumen. Prog. Lipid Res. 17:21-54.

11. Harfoot, C. G and Hazlewood, G. P. 1988. Lipid metabolism in the rumen. In : The Rumen Microbial Ecosystem (ed. P. N. Hobson). London, New-York: Elsevier Applied Science. pp.285-322.

12. Hussein, H. S., Merchen, N. R. and Fahey, G. C. 1996. Effects of chemical treatment of whole canola seed on digestion of long-chain fatty acids by steers fed high or low forage diets. J. Dairy Sci. 79:87-97.

13. Ip, C., Singh, M., Thompson, H. J. and Scimeca, J. A. 1994. Conjugated linoleic acid suppresses mammary carcinogensis and proliferate activity of the mammary gland in the rat. Cancer Res. 54:12121215.

14. Jahreis, G., Fritsche, J. and Steinhart, H. 1997. Conjugated linoleic acid in milk fat - high variation depending on production system. Nutr. Res. 17:14791484.

15. Jenkins, T. C and Palmquist, D. L. 1984. Effect of fatty acids or calcium soaps on rumen and total nutrient digestibility of dairy rations. J. Dairy Sci. 67:978-986.

16. Jenkins, T. C. 1993. Lipid metabolism in the rumen. J. Dairy Sci. 76:3851-3863.

17. Jiang, J., Bjoerck, L., Fonden, R. and Emanuelson, M. 1996. Occurrence of conjugated cis- 9 , trans-11 octadecadienoic acid in bovine milk: Effects of feed and dietary regimen. J. Dairy Sci. 79:435-445.

18. Kalscheur, K. F., Teter, B. B., Piperova, L. S. and Erdman, R. A. 1997a. Effect of dietary forage concentration and buffer addition on duodenal flow of trans-C18:1 fatty acids and milk fat production in dairy cows. J. Dairy Sci. 80:2104-2114.

19. Kalscheur, K. F., Teter, B. B., Piperova, L. S. and Erdman, R. A. 1997b. Effect of fat source on duodenal flow of trans-C18:1 fatty acids and milk fat production in dairy cows. J. Dairy Sci. 80:2115-2126.

20. Klusmeyer, T. H. and Clark, J. H. 1991. Effects of dietary fat and protein on fatty acid flow to the duodenum and in milk produced by dairy cows. J. Dairy Sci. 74:3055-3067.

21. Klusmeyer, T. H., Lynch, G. L., Clark, J. H. and Nelson, D. R. 1991. Effects of calcium salts of fatty acids and protein source on ruminal fermentation and nutrient flow to the duodenum of cows. J. Dairy Sci. 74:2206-2219.

22. Lawes Agricultural Trust, 1990. GENSTAT V mark 2.2. Rothamsted Experimental Station, Harpenden, UK.

23. Maczulak, A. E., Dehority, B. A. and Palmquist, D. L. 1981. Effects of long-chain fatty acids on growth of rumen bacteria. Appl. Environ. Microbiol. 42:856-862.

24. McDougall, E. I. 1948. Studies on ruminant saliva. I. The composition and output of sheep's saliva. Biochem. J. 43:99-109.

25. Merry, R. J., Smith, R. H. and McAllans, A. B. 1987. Studies of rumen function in an in vitro continuous culture system. Arch. Anim. Nutr. Berlin. 37:475-488.

26. Merten, D. R. 1977. Dietary fiber components: relationships to the rate and extent of ruminal digestion. Fed. Proc. 36:187-192.

27. Ministry of Agriculture, Fisheries and Food. 1992. Prediction of energy value of compound feeding stuffs for farm animals. Summary of recommendations of a working party sponsored by the Ministry of Agriculture, Fisheries and Food, United Kingdom.

28. Mould, F. L., Ørskov, E. R. and Mann, S. O. 1983. Associative effects of mixed feeds. I. Effects of 
type and level of supplementation and the influence of rumen fluid $\mathrm{pH}$ on cellulolysis in vivo and dry matter digestion of various roughages. Anim. Feed Sci. Technol. 10:15-30.

29. Nocek, J. E. 1997. Bovine acidosis: Implications on laminitis. J. Dairy Sci. 80:1005-1028.

30. Palmquist, D. L. and Schanbacher, F. L. 1991. Dietary fat composition influences fatty acid composition of milk fat globule membrane in lactating cows. Lipids. 26:718-722.

31. Scollan, N. D., Choi, N. J., Fisher, A.V., Enser, M. and Wood, J. D. 2001a. Manipulating the fatty acid composition of muscle and adipose tissue in beef cattle. Br. J. Nutr. 85: 115-124.

32. Scollan, N. D., Dhanoa, M. S., Choi, N, J., Maeng, W. J., Enser, M. and Wood, J. D . 2001b. Digestion of long chain fatty acids from different feed sources and their effect on the rumen function of steers. J. Agric. Sci., Camb. 136:345-355.

33. Scott, T. W., Bready, P. J., Royal, A. J. and Cook, L. J. 1972. Oil seed supplements for the production of polyunsaturated ruminant milk fat. Search 3:170-171.

34. Simopoulos, A. P. 1988. Diet, exercise and caloric balance. J. Am. Med. Assoc. 260:1953.

35. Stanton, C., Lawless, F., Kjellmer, G., Harrington, D., Devery, R., Connolly, J. F. and Murphy, J. 1997. Dietary influences on bovine milk cis-9, 11-trans conjugated linoleic acid content. J. Food Sci. 62:1083-1086.

36. Van Nevel, C. J. and Demeyer, D. I. 1996. Effect of $\mathrm{pH}$ on biohydrogenation of polyunsaturated fatty acids and their Ca-salts by rumen microorganisms in vitro. Arch. Anim. Nutr. 49:151-158.

37. Van Soest, P. J., Robertson, J. B. and Lewis, B. A. 1991. Methods for dietary fiber, neutral detergent fiber and non starch polysaccharides in relation to animal nutrition. J. Dairy Sci. 74:3568-3597.

38. Wu, Z., Ohajuruka, O. A. and Palmquist, D. L. 1991. Ruminal synthesis, biohydrogenation, and digestibility of fatty acids by dairy cows. J. Dairy Sci. 74:3025-3034.

(접수일자 : 2003. 3. 19. / 채택일자 : 2003. 5. 12.) 